\title{
Effectiveness of Three Post-Harvest Rehabilitation Treatments for Runoff and Sediment Reduction on Skid Trails in the Hyrcanian Forests
}

\author{
Meghdad Jourgholami, Masoumeh Ahmadi, Farzam Tavankar, Rodolfo Picchio
}

\begin{abstract}
Ground-based skidding operations can lead to soil compaction and displacement, which could cause negative effects on forest soil. Hence, some efforts such as forestry best management practices (BMPs) must be implemented in the prone area to mitigate these possible impacts. Several materials and treatments have been adopted to suppress these adverse effects by increasing the ground cover. However, the effects of mulch treatments on runoff and sediment yield are inconclusive with a diverse range of effectiveness. For these reasons, in this research mulch treatments were tested as to determine how the application of organic mulch amendments such as straw and leaf litter and contour-felled logs would alleviate the runoff and sediment yield on machine operating trails and ensure successful hillslope stabilization. The aims of the study were to analyse and compare the effectiveness of leaf litter (LM) and straw mulch (SM) rate and different distances of contour-felled logs (CFL) to mitigate the runoff and sediment yield, and examine the impact of rainfall intensity on effectiveness of litter mulch, straw mulch, and contour-felled logs. Totally, 30 bounded runoff plots in the machine operating trails and four treatments including litter mulch (LMR1: 0.62, LMR2: 1.24, and LMR3: $1.86 \mathrm{~kg} \mathrm{~m}^{-2}$ ), straw mulch (SMR1: 0.45, SMR2: 0.92, and SMR3: $1.34 \mathrm{~kg} \mathrm{~m}^{-2}$ ), contour-felled logs (CFL10: 10, CFL20: 20, and CFL30: $30 \mathrm{~m}$ ), and untreated area were established in triplicate with $4 \mathrm{~m}$ width and $100 \mathrm{~m}$ length. During the study period, the runoff and sediment yield in the untreated trails $(U)$ were $2.36 \mathrm{~mm}$ and $11.84 \mathrm{~g} \mathrm{~m}^{-2}$. Straw (from 41.5 to $60.6 \%$ ) and litter mulch (from 38.1 to $55.1 \%$ ), and contour-felled logs treatments (from 70.8 to $88.1 \%$ ) significantly decreased the runoff, compared to U treatment. Results show that mulch treatments with three different levels of Litter Mulch Rate, LMR1, LMR2, and LMR3 decreased mean sediment by 46.6, 64.0 and $71.8 \%$, in the treatments with three different levels of Straw Mulch Rate, SMR1,SMR2, and SMR3 decreased mean sediment by 42.9, 62.1, and $69.9 \%$, and in the treatments with three different distances of Contour-Felled Logs, CFL10, CFL20, and CFL30 decreased mean sediment by 90.6, 94.7 and $88.3 \%$ comparing to $U$, respectively. The relationships of the runoff and sediment responses to increasing mulching rate of litter and straw followed as negative logarithmic curves, but the decreasing-increasing trends were observed in runoff and sediment yield as the distance between contour-felled logs increased from 10 to $30 \mathrm{~m}$. Polynomial regression equations were developed for predicting the runoff and sediment yield as a function of the application rate of litter and straw mulch and the distance between contour-felled logs, and rainfall intensity. We concluded that contour-felled logs treatment was more effective than both litter and straw mulch to mitigate the runoff, runoff coefficient, and sediment yield on machine operating trails. As a management measure, it could be possible to propose that the contour-felled logs with a distance of $20 \mathrm{~m}$ be prescribed to protect the machine operating trails from the negative effects of surface waterflow.
\end{abstract}

Keywords: forest utilization, soil compaction, runoff flow, soil loss, mulching, litter mulch, straw mulch, contour-felled logs 


\section{Introduction}

Ground-based skidding operations by forestry machines can lead to soil compaction and displacement, which could cause negative hydrological and physical effects on forest soil depending on forest site characteristics (Picchio et al. 2019), silvicultural treatment (Picchio et al. 2016) and forest logging typologies and quality (Hansson et al. 2018, Jourgholami et al. 2019a). After ground-based skidding operations, soil compaction occurs which causes an increase in soil bulk density and a decrease of total porosity (Batey 2009, Picchio et al. 2012, Nawaz et al. 2013 and 2016, Jourgholami et al. 2019b). Moreover, soil disturbance leads to the elimination of the litter layer, and also results in reduced water absorption capacity and decreases water infiltration rate as well as saturated hydraulic conductivity (Hamza and Anderson 2005, Jourgholami et al. 2018a and b, Poltorak et al. 2018). The impact of raindrops on the bare mineral soil causes the surface runoff flow to increase causing detachment, transport, and deposit of the soil particles. This leads to soil loss, sedimentation, and flooding hazards that have a substantial impact on downstream municipal infrastructures (Jiang et al. 2019).

Machine operating trails and depots were considered as major sources of runoff and sediment generation (Cristan et al. 2016). Hence, some efforts such as forestry best management practices (BMPs) must be implemented in the prone area to mitigate the adverse effects of forestry machines on forest soil (Wear et al. 2013, Cristan et al. 2016). Several materials and treatments have been adopted to suppress the adverse effects of ground-based skidding operations including mulches and seeding by increasing the ground cover (Jourgholami and Etehadi Abari 2017). Other alternatives, such as log erosion barriers (contour-felled logs) are installed to decrease the erosive power of runoff, increase the infiltration rate, store the eroded materials, and reinforce and stabilize the hillslopes (Wagenbrenner et al. 2006, Kim et al. 2008, Robichaud et al. 2008a). Generally, in agriculture, mulch includes any organic and inorganic material such as agricultural straw, plant leaves, plastic film, wood strands, wood chips, wood shreds, gravel, and loose soil, which is dispersed on the soil surface to protect it from raindrop impact, soil sealing, and evaporation (Smets et al. 2008, Jordán et al. 2010). However, the effects of mulch treatments on runoff and sediment yield are inconclusive with a diverse range of effectiveness (Robichaud et al. 2016, Jourgholami and Etehadi Abari 2017). In addition, mulch treatments by coverage of the soil surface can absorb the kinetic energy of raindrops, reduce splash erosion and soil detachment, decrease the transport capacity of eroded sediment, alleviate temperature fluctuations, and enhance infiltration rate (Robichaud et al. 2008a, Jordán et al. 2010).

Previous studies have demonstrated that the distribution of logs per area, quality of installation, storage capacity of sediment, and rainfall intensity were the main important factors that influenced the effectiveness of contour-fell log treatment (Wagenbrenner et al. 2006, Kim et al. 2008, Robichaud et al. 2008a). The effectiveness of contour-felled log treatment mostly depends on the log distribution, installation, sediment storage capacity, and storm intensity (Wagenbrenner et al. 2006). Log Erosion Barriers (LEBs) can increase the infiltration rate of surface flow and decrease erosive power and velocity of runoff, and reduce soil loss (Yanosek et al. 2006). Jourgholami et al. (2018b) indicated that the useful life of contour-fell log and also the storage capacity decreased after installation due to sediment accumulation and log degradation. In addition, Kim et al. (2008) concluded that the ineffectiveness of LEBs for post-fire vegetation recovery was attributed to the small diameter of logs $(<10 \mathrm{~cm})$ that decreased the runoff storage capacity behind logs. In the western United States, installing of LEBs can mitigate runoff and sediment yield compared to control watershed (Robichaud et al. 2008b).

Newly fallen leaves and rice straw can be applied as mulch to protect surface mineral soil against rain drop and throughfall impact, detachment of soil particles, and prevent soil aggregate losses, which resulted in a decrease of surface runoff and soil loss (Sayer 2006, Robichaud et al. 2013, Li et al. 2014, Prats et al. 2014, Vega et al. 2014, Vega et al. 2015, Fernández and Vega 2016, Jourgholami et al. 2019a). Under laboratory conditions in Northern China, the litter rate mulching decreased the runoff by $29.5-31.3 \%$, compared to bare plot (Li et al. 2014). In contrast, Jourgholami et al. (2019a) found that increasing litter mulch rate from 0.42 to $1.69 \mathrm{~kg} \mathrm{~m}^{2}$ significantly reduced the runoff (by $49-79 \%$ ) and sediment yield (by 76-93\%) on the machine operating trails, compared to the untreated treatment. In the Hyrcanian deciduous forests in northern Iran, spreading straw mulch and sawdust mulch on the skid trail decreased the runoff by $36.5 \%$ and $72.8 \%$, respectively, and also reduced sediment by $51.9 \%$ and $94.9 \%$, respectively, compared to untreated trails (Jourgholami and Etehadi Abari 2017).

The application rate of mulch can significantly influence the effectiveness of mulch for suppressing the runoff and soil loss (Li et al. 2013). In contrast, Li et al. (2014) concluded that the litter mass (rate) has no significant linear correlation with runoff yield. Accordingly, several studies determined that the rate of 
straw and leaf litter mulch or mulch thickness affected the surface runoff flow and sediment yield (Wagenbrenner et al. 2006, Kim et al. 2008, Robichaud et al. 2008a, Jourgholami and Etehadi Abari 2017, Jourgholami et al. 2019a). Previous studies have proved that rainfall intensity significantly contributed to runoff and sediment yield under different treatments (Geißler et al. 2012, Li et al. 2014). By increasing rainfall intensity, runoff and soil loss reduced as litter rate increased (Jourgholami et al. 2019a). Similarly, Jourgholami and Etehadi Abari (2017) found a linear increase of runoff with the increase of the rainfall intensity.

The aims of the study were to (1) analyze and compare the effectiveness of leaf litter and straw mulch rate and different distance of contour-felled logs to mitigate runoff and sediment yield, and (2) examine the impact of rainfall intensity on effectiveness of leaf litter, straw mulch, and contour-felled logs. The main hypothesis was that the application of organic mulch amendments such as straw and leaf litter and contour-felled logs would alleviate the runoff and sediment yield on machine operating trails and ensure successful hillslope stabilization.

\section{Materials and Methods}

\subsection{Study Areas}

This study was conducted in the compartment no. 617 of the Tangar district in the Tyrumrud watershed of the Hyrcanian forests (Fig. 1). The ground slope ranged from $10-45 \%$ facing east. The study site has an elevation ranging from 510 to $570 \mathrm{~m}$ a.s.l. and the mean annual precipitation is $1360 \mathrm{~mm}$, falling mostly as rain, with the highest and lowest amounts occurring in October and July, respectively. The climate of the study area is humid and temperate with a mean annual temperature of $14.2^{\circ} \mathrm{C}$, with the hottest in July $\left(23.7^{\circ} \mathrm{C}\right)$ and coldest in January $\left(6.8^{\circ} \mathrm{C}\right)$, respectively. According to the United States Department of Agriculture (USDA) soil taxonomy, the soils are Alfisols and the soil texture was classified as clay loam from limestone. The study area is a part of the Hyrcanian forests, which is a natural deciduous uneven-aged forest dominated with species including hornbeam (Carpinus betulus L.), velvet maple (Acer velutinum Boiss.), oak (Quercus castaneifolia C.A.M.), Caucasian alder (Alnus subcordata C.A.M.), and Persian ironwood (Parrotia persica C.A.M.) with the average growing stock of $268 \mathrm{~m}^{3} \mathrm{ha}^{-1}$. Tree felling and delimbing were performed with chain-saws. Afterwards, a TAF E655 (wheeled skidder) was used to extract logs (5-15 m in length) from the stand to the roadside landings in
May 2016. The skidder was equipped with a $49 \mathrm{~kW}$ engine, weighed 6.8 tonnes unloaded and was fitted with size 18.4-26 tires inflated to $659 \mathrm{kPa}$ on both front and rear axles. The average skidding load was $2.86 \mathrm{~m}^{3}$ per cycle and the skid trail longitudinal gradient ranged between $20-25 \%$, with a mean skid trail width of $3.4 \mathrm{~m}$.

\subsection{Experimental Design and Measurements}

Totally, 30 bounded runoff plots in the machine operating trails with the same slope (20-25\%) and machine traffic level with a completely randomized design were selected following ground-based skidding operations for runoff plot establishment. In the study area, four treatments were triplicately established including litter mulch (LM) with different rate, straw mulch (SM) with different rate, contour-felled logs (CFL) with different distance, and untreated area (U) (Fig. 1). Therefore, treatments in this study included; $\mathrm{U}=$ Untreated area, LMR1 $=$ rate of $0.62 \mathrm{~kg} \mathrm{~m}^{-2}, \mathrm{LMR} 2=$ rate of $1.24 \mathrm{~kg} \mathrm{~m}^{-2}$, LMR3 = rate of $1.86 \mathrm{~kg} \mathrm{~m}^{-2}$, SMR1 = rate of $0.45 \mathrm{~kg} \mathrm{~m}^{-2}$, SMR2 = rate of $0.92 \mathrm{~kg} \mathrm{~m}^{-2}, \mathrm{SMR} 3=$ rate of $1.34 \mathrm{~kg} \mathrm{~m}^{-2}$, CFL10 = with distance of $10 \mathrm{~m}$, CFL20 = with distance of $20 \mathrm{~m}$, CFL30 $=$ with distance of $30 \mathrm{~m}$.

In each treatment, runoff plots $4 \mathrm{~m}$ wide and $100 \mathrm{~m}$ long were randomly established on the machine operating trails. Weed free rice straw mulch was applied with $100 \%$ coverage. Rice straws were, on average, 4-17 cm long and 4-6 mm thick (Robichaud et al. 2008a, Jourgholami and Etehadi Abari 2017). The litter mulch treatment was composed of litter from two species, including hornbeam and velvet maple that was manually spread on the skid trail surface with a combination of 1:1 undecomposed litter weight of hornbeam and velvet maple (Li et al. 2014). The contour-felled log (CFL) erosion barriers were applied by establishing the logs with diameters ranging from 25 to $30 \mathrm{~cm}$ and $4 \mathrm{~m}$ in length in a diagonal direction to the longitudinal axis of the skid trails (Jourgholami et al. 2018b). The distance between each contour-felled log varied in different treatments, which was set at 10,20, and $30 \mathrm{~m}$. The untreated area or bare machine operating trail had no ground cover protection and had the same traffic intensity and slope, aspect, and vegetation cover as the other treatments. The amounts of runoff in each runoff plot were measured for a total of 25 rainfall events during the study period (i.e., from July 03, 2016 through November 20, 2016). The perimeter of the runoff plots were bounded by wooden boards inserted $20 \mathrm{~cm}$ inside the soil and extended $20 \mathrm{~cm}$ above the surface and acted as a measure to eliminate water in/to the plots (Kim et al. 2014). For each runoff plot, the runoff 
was collected and routed to a $0.20 \mathrm{~m}^{3}$ storage tank. In all cases, the storage tanks were located at the lower end of the plots. To determine the sediment yield, a subsample of 1 liter for each runoff plot was measured, filtered through filter paper with size of $2 \mu \mathrm{m}$, and oven-dried at $105{ }^{\circ} \mathrm{C}$ for $24 \mathrm{~h}$ (Sosa-Pérez and MacDonald 2017). Three rainfall gauges were placed in an open area neighboring the stand (located less than $100 \mathrm{~m}$ away from the runoff plots) to measure gross rainfall. A manual rain collector with diameter of $9 \mathrm{~cm}$ and height of $20 \mathrm{~cm}$ was used to measure the amount of throughfall underneath the forest canopy within each runoff plot (Kim et al. 2014). Runoff coefficient (RC) was measured by Eq. 1 as follows (Li et al. 2014):

$$
R C=\frac{R V}{T R}
$$

Where:

RV runoff volume, $\mathrm{mm}$

TR total rainfall, $\mathrm{mm}$.

Soil samples from the top $5 \mathrm{~cm}$ in each runoff plot were taken with a steel cylinder (with length of $40 \mathrm{~mm}$ and diameter of $56 \mathrm{~mm}$ ) to measure the variables including soil bulk density, total porosity, organic matter content, canopy cover, and soil particle-size distribution. In each runoff plot, five sampling points randomly selected, thus totaling 150 soil samples, were measured. Soil samples were placed in plastic bags, labeled, and transported to the laboratory. A portion of soil samples was weighed after collecting and then oven dried at $105^{\circ} \mathrm{C}$ until a constant mass was reached to determine the moisture content and the soil bulk density. In order to determine the soil particle size distribution for particles smaller than $0.075 \mathrm{~mm}$, the hydrometer method was used (Gee and Bauder 1986), and the larger particles were separated by sieving through a series of sieves of varying apertures. To assess the soil particle density, the ASTM D854-00 2000 standard was applied and total porosity was determined by Eq. 2 as follows (Jourgholami et al. 2018a):

$$
T P=\left[1-\left(\frac{d s}{p d}\right)\right] \times 100
$$

Where:

TP total porosity, $\%$

ds bulk density, $\mathrm{g} \mathrm{cm}^{-3}$

dp particle density, $\mathrm{g} \mathrm{cm}^{-3}$.

The Walkley-Black technique (Walkley and Black 1934) was applied to determine soil organic C. An ocular observation was conducted in three points at each runoff plots to predict the canopy cover.

The multivariate polynomial regression (Sinha 2013) model of the form (Eq. 1) was used for developing the relationship between runoff and sediment with rainfall intensity and mulch rate and contour-felled logs with different distance:

$$
\begin{aligned}
Y= & a+b x_{1}+c x_{2}+d x_{1}^{2}+e x_{2}^{2}+f x_{1}^{3}+ \\
& +g x_{2}^{3}+h x_{1} x_{2}+i x_{1}^{2} x_{2}+j x_{1} x_{2}^{2}
\end{aligned}
$$

Where:

$\begin{array}{ll}a, b, c & \text { constant variables } \\ x_{1} \text { and } x_{2} & \text { different variables. }\end{array}$

\subsection{Statistical Analysis}

A factorial experiment with a complete block design was randomly assigned to the different rates of litter and straw mulch, and contour-felled logs. The normal distribution of data was checked with the use of the Kolmogorov-Smirnov test. Levene's test was conducted for testing the homogeneity of variance among treatments. In order to compare the runoff, runoff coefficient, and sediment yield among treatments (litter and straw mulch, contour-felled logs, and untreated trails $(\mathrm{U})$, a one-way analysis of variance (ANOVA) was performed. Duncan's Multiple Range tests were applied to find differences among litter and straw mulch, contour-felled logs, and untreated trails (U) means at $p \leq 0.05$, after finding significant differences among treatments by the ANOVA. The Pearson correlation was conducted to examine the relationships between treatments, runoff, sediment yield, studied soil properties, and canopy cover. The SPSS software package (release 17.0; SPSS, Chicago, IL, USA) was used to perform all statistical tests. The relationship between runoff and sediment yield with the mulch rate (Litter mulch rate, LMR; Straw mulch rate, SMR; contour-felled logs with different distance, CFL), and rainfall intensity (RI) were plotted and predicted by the multivariate polynomial regression model using the Curve Expert Professional 1.6 software.

\section{Results}

\subsection{Rainfall and Site Characteristics}

For the study period from 3 July 2016 to 20 November 2016, a total of 25 rainfall events were measured, with a total of $1003.2 \mathrm{~mm}$, ranging from $7.4 \mathrm{~mm} /$ day to $94 \mathrm{~mm} /$ day with an average of $40.1 \mathrm{~mm} /$ day.

As Duncan's test indicated, significant differences in soil bulk density, total porosity, organic matter 
content, canopy cover, sand, clay, and silt among the treatments were not found before the study started in 2016 in the runoff plots, (Table 1). Results of the Pearson correlation show a significant negative relationship between treatment and runoff $(r=0.75)$, and also sediment yield $(r=-0.78)$. Meanwhile, soil bulk density, total porosity, organic matter content, canopy cover, sand, clay, and silt were not significantly correlated with treatment, amount of runoff and sediment yield (Table 2).

\subsection{Runoff and Runoff Coefficient}

Significant differences in runoff and runoff coefficient among treatments were found after applying litter and straw mulch and contour-felled logs treatment on machine operating trails. The runoff was significantly higher on the $\mathrm{U}$ treatment $(2.36 \mathrm{~mm})$, followed by SMR1>LMR1 SMR2, whereas the lowest runoff was observed on CFL20 $(0.28 \mathrm{~mm})$ followed by CFL10. Compared with $\mathrm{U}$ treatment, runoff in the treatments LMR1, LMR2, and LMR3 decreased by 41.5, 54.7, and $60.6 \%$, respectively. Runoff in the treatments SMR1, SMR2, and SMR3 decreased by 38.1, 50.4, and 55.1\%, respectively, as compared to U treatment. Likewise, compared with $\mathrm{U}$ treatment, runoff in the treatments CFL10, CFL20, and CFL30 decreased by 83.5, 88.1, and $70.8 \%$, respectively (Table 4 ).

Straw and litter mulch, and contour-felled log treatments significantly decreased runoff coefficient, as compared to untreated trails (U) (Table 3). Mean runoff coefficient were in the order of 0.03 in LMR1 $>0.023$ in LMR2 $>0.019$ in LMR3 at the litter mulch, and 0.032 in SMR1 $>0.025$ in SMR2 $>0.022$ in SMR3 at the straw mulch, respectively. Also, the lowest runoff coefficient was observed on CFL20 (0.005) $\approx$ CFL10 (0.007) followed by CFL30 (Table 4).

Results show that runoff significantly decreased by increasing the application rate of both litter and straw mulch as shown by logarithmic curves (Fig. A1A). Similarly, when the distance between contour-felled logs from 10 to $30 \mathrm{~m}$ increased, runoff significantly shows two trends, first decreasing from $10 \mathrm{~m}$ to $20 \mathrm{~m}$, then increasing from $20 \mathrm{~m}$ to $30 \mathrm{~m}$, as compared to $\mathrm{U}$ treatment (Fig. A1B).

Time sequences of rainfall intensity $(\mathrm{mm} /$ day) and runoff under the litter mulch, straw mulch, and contour-felled logs are shown in Fig. A2. In the U treatment, the highest runoff values of $5.31 \mathrm{~mm}$ and $5.07 \mathrm{~mm}$ were observed at the corresponding rainfall intensity of $77.4 \mathrm{~mm}$ and $93.8 \mathrm{~mm}$ on 17 September and on 21 October, respectively (Fig. A2). During the study period, runoff values were in the range of 0.28 to $3.25 \mathrm{~mm}$, 0.19 to $2.67 \mathrm{~mm}$, and 0.21 to $2.5 \mathrm{~mm}$ when applying the LMR1, LMR2, and LMR3, respectively (Fig. A2A). Also, runoff values were in the range of 0.35 to $3.48 \mathrm{~mm}$, 0.17 to $3.03 \mathrm{~mm}$, and 0.29 to $2.76 \mathrm{~mm}$ when applying the SMR1, SMR2, and SMR3, respectively (Fig. A2B). The lowest values of runoff were within the range of 0.19 to $1.22 \mathrm{~mm}, 0.02$ to $0.91 \mathrm{~mm}$, and 0.2 to $2.0 \mathrm{~mm}$ when applying the CFL10, CFL20, and CFL30, respectively (Fig. A2C).

\subsection{Sediment Yield}

Straw and litter mulch, and contour-felled log treatments significantly decreased sediment yield, as compared to untreated trails (U) (Table 3). The mulch treatments with LMR1, LMR1, and LMR1 decreased mean sediment yield by $46.6,64.0$ and $71.8 \%$, respectively, compared with the U. Sediment in the treatments SMR1, SMR2, and SMR3 decreased by 42.9, 62.1 , and $69.9 \%$, respectively, as compared to U treatment. However, the mean sediment was 90.6, 94.7 and 88.3\% lower in the treatments with CFL10, CFL20, and CFL30 compared to U, respectively (Table 4).

The relationship of the sediment responses to increasing mulching rate of litter and straw followed negative logarithmic curves (Fig. A1C). A decreasingincreasing trend was observed in sediment yield as distance between contour-felled logs from 10 to $30 \mathrm{~m}$ increased (Fig. A1D).

Time sequences of rainfall intensity ( $\mathrm{mm} /$ day) and sediment yield under the litter mulch, straw mulch, and contour-felled logs are shown in Fig. A2. In the U treatment, the highest sediment values of 30.37 and $27.67 \mathrm{~g} \mathrm{~m}^{-2} \mathrm{~mm}$ were observed at the corresponding rainfall intensity of 93.8 and $77.4 \mathrm{~mm}$ on 21 October and on 17 September, respectively (Fig. A2D). During the study period, sediment yield values were in the range of 0.61 to $18.83 \mathrm{~g} \mathrm{~m}^{-2}, 0.44$ to $13.36 \mathrm{~g} \mathrm{~m}^{-2}$, and 0.52 to $9.36 \mathrm{~g} \mathrm{~m}^{-2}$ after applying the LMR1, LMR2, and LMR3, respectively (Fig. A2D). Sediment yield values with straw were in the range of 0.75 to $19.67 \mathrm{~g} \mathrm{~m}^{-2}, 0.33$ to $12.73 \mathrm{~g} \mathrm{~m}^{-2}$, and 0.52 to $10.32 \mathrm{~g} \mathrm{~m}^{-2}$ when applying the SMR1, SMR2, and SMR3, respectively (Fig. A2E). The lowest values of sediment yield were within the range of 0.53 to $3.14 \mathrm{~g} \mathrm{~m}^{-2}, 0.08$ to $1.82 \mathrm{~g} \mathrm{~m}^{-2}$, and 0.21 to $3.89 \mathrm{~g} \mathrm{~m}^{-2}$ when applying the CFL10, CFL20, and CFL30, respectively (Fig. A2F).

\subsection{Runoff and Sediment Yield Model}

The developed polynomial regression model for the relationship between runoff and sediment yield, mulch rate (Litter mulch rate; LMR, Straw mulch rate; SMR, contour-felled logs; CFL), and rainfall intensity (RI) were as follows (Eq. 4-9): 
Runoff model for litter mulch:

$$
\begin{gathered}
\text { Runoff }_{\text {litter }}=0.0261-0.888 \times L M R+0.055 \times R I+ \\
+1.039 \times L M R^{2}+0.0002 \times R I^{2}- \\
-0.349 \times L M R^{3}-0.000002 \times R I^{3}-0.037 \times L M R \times R I+ \\
+0.012 \times L M R^{2} \times R I-0.00001 \times L M R \times R I^{2}
\end{gathered}
$$

Runoff model for straw mulch:

$$
\begin{gathered}
\text { Runoff }_{\text {straw }}=0.043-1.216 \times S M R+0.054 \times R I+ \\
+1.842 \times S M R^{2}+0.00015 \times R I^{2}- \\
-0.824 \times S M R^{3}-0.000001 \times R I^{3}-0.043 \times S M R \times R I+ \\
+0.0197 \times S M R^{2} \times R I-0.00003 \times S M R \times R I^{2}
\end{gathered}
$$

Runoff model for contour-felled logs:

$$
\begin{gathered}
\text { Runoff }_{C F L}=0.164-0.121 \times C F L+0.047 \times R I+ \\
+0.01 \times C F L^{2}+0.0003 \times R I^{2}-
\end{gathered}
$$

$$
\begin{gathered}
-0.0002 \times C F L^{3}-0.000002 \times R I^{3}-0.005 \times C F L \times R I+ \\
+0.00014 \times C F L^{2} \times R I-0.0000001 \times C F L \times R I^{2} \quad \text { (6) }
\end{gathered}
$$

Sediment yield model for litter mulch:

$$
\begin{gathered}
\text { Sediment }_{\text {litter }}=-0.011-6.532 \times L M R+0.326 \times R I+ \\
+6.055 \times L M R^{2}-0.0015 \times R I^{2}- \\
-1.62 \times L M R^{3}+0.00001 \times R I^{3}-0.144 \times L M R \times R I+ \\
+0.036 \times L M R^{2} \times R I-0.0003 \times L M R \times R I^{2}
\end{gathered}
$$

Sediment yield model for straw mulch:

$$
\begin{gathered}
\text { Sediment }_{\text {straw }}=0.036-7.62 \times S M R+ \\
+0.311 \times R I+8.86 \times S M R^{2}-0.0008 \times R I^{2}- \\
-2.991 \times S M R^{3}+0.000009 \times R I^{3}-0.188 \times S M R \times R I+ \\
+0.056 \times S M R^{2} \times R I-0.0002 \times S M R \times R I^{2}
\end{gathered}
$$

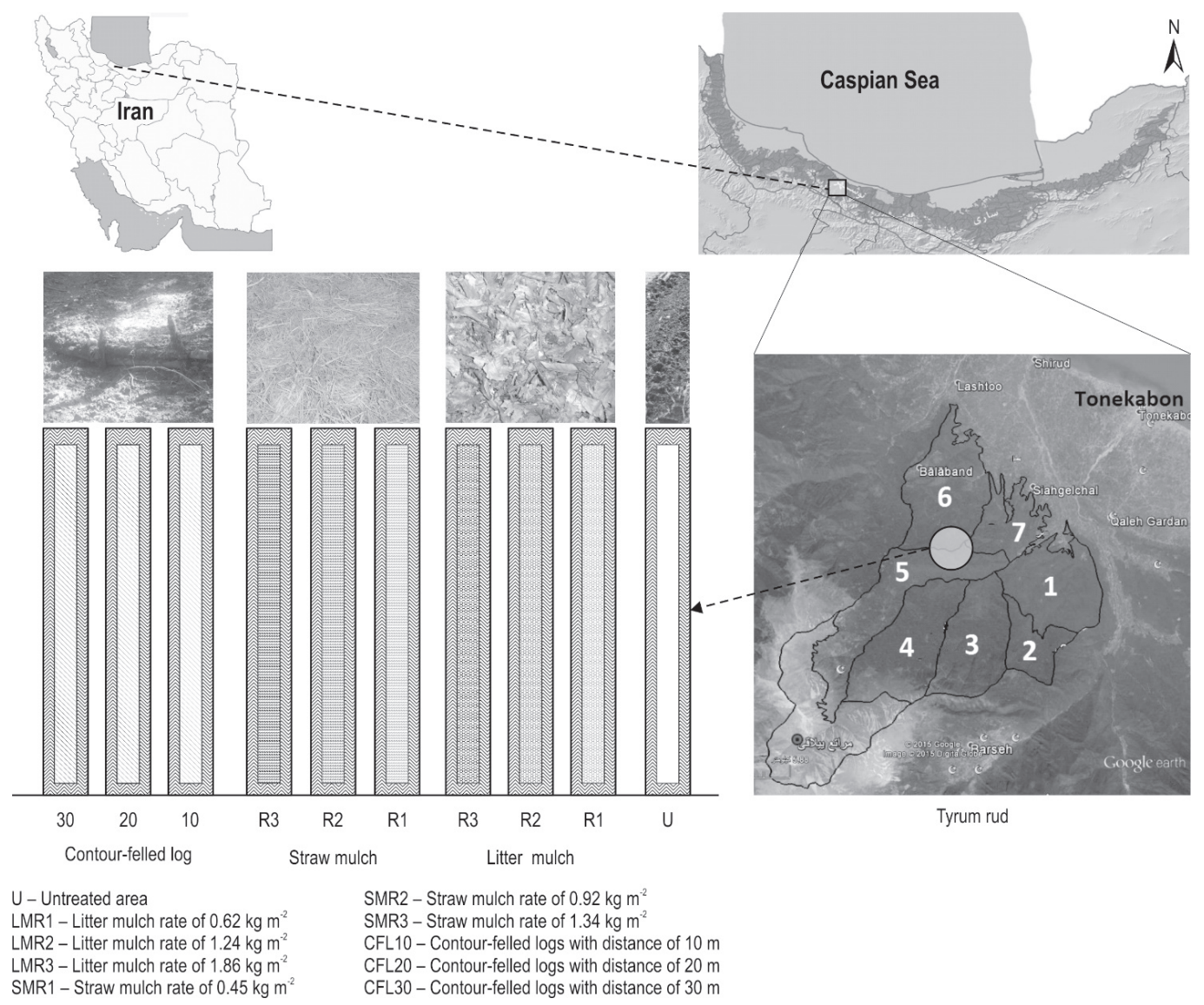

Fig. 1 Study area in Tyrumrud forests in the Hyrcanian forests, schematic of the experimental design on machine operating trail 
Sediment yield model for contour-felled logs:

$$
\begin{gathered}
\text { Sediment }_{C F L}=0.283-0.747 \times C F L+ \\
+0.313 \times R I+0.068 \times C F L^{2}-0.001 \times R I^{2}- \\
-0.002 \times C F L^{3}+0.000009 \times R I^{3}-0.028 \times C F L \times R I+ \\
+0.0007 \times C F L^{2} \times R I-0.00001 \times C F L \times R I^{2}
\end{gathered}
$$

The coefficients of determination for the Eqs. 3 to 8 were $79.4,82.1,87.4,82.5,81.1$ and $86.4 \%$, respectively. Based on multivariate polynomial regression analyses, predicted model for runoff and sediment yield in function of litter and straw mulch and contour-felled logs, and rainfall intensity are depicted in Figs. 2 and 3. Irrespective of the applying rates for litter and straw mulch, runoff and sediment steadily increased as rainfall intensity increased. Furthermore, the changes in runoff and sediment yield after the application of litter and straw mulch have the same trend. Also, at low rainfall intensities, the effects of increasing application rate for both litter and straw mulch were not noteworthy. However, at high rainfall intensities $(>50 \mathrm{~mm})$, the increase in the application rate for both litter and straw mulch significantly resulted in a reduction of runoff and sediment yield (Figs. 2A, B and 3A, B). For each rainfall intensity, runoff and sediment yield show two trends with increasing distance between contour-felled logs; first, decreased from $10 \mathrm{~m}$ to $20 \mathrm{~m}$, and then, increased from the distance of $20 \mathrm{~m}$ to $30 \mathrm{~m}$ (Figs. 2C and 3C).

\subsection{Figures, Tables and Schemes}

Table 1 Mean values $( \pm S D)$ of different soil physical properties and canopy cover before the experiment started in 2016 in the runoff plots with different treatments

\begin{tabular}{|l|c|c|c|c|c|c|c|}
\hline Treatment & $\begin{array}{c}\text { Bulk density } \\
\text { Mg m }^{-3}\end{array}$ & $\begin{array}{c}\text { Total porosity } \\
\%\end{array}$ & $\begin{array}{c}\text { Organic matter } \\
\text { content, } \%\end{array}$ & $\begin{array}{c}\text { Canopy cover } \\
\%\end{array}$ & $\begin{array}{c}\text { Sand } \\
\%\end{array}$ & $\begin{array}{c}\text { Clay } \\
\%\end{array}$ & $\begin{array}{c}\text { Silt } \\
\%\end{array}$ \\
\hline U & $1.35 \pm 0.02 \mathrm{~A}$ & $47.9 \pm 0.85 \mathrm{~A}$ & $2.7 \pm 0.30 \mathrm{~A}$ & $81.17 \pm 2.46 \mathrm{~A}$ & $24.12 \pm 1.20 \mathrm{~A}$ & $32.21 \pm 1.33 \mathrm{~A}$ & $43.67 \pm 2.52 \mathrm{~A}$ \\
\hline LMR1 & $1.36 \pm 0.04 \mathrm{~A}$ & $47.73 \pm 1.55 \mathrm{~A}$ & $2.41 \pm 0.37 \mathrm{~A}$ & $79.73 \pm 2.47 \mathrm{~A}$ & $25.67 \pm 0.58 \mathrm{~A}$ & $33.21 \pm 1.23 \mathrm{~A}$ & $41.12 \pm 2.30 \mathrm{~A}$ \\
\hline LMR2 & $1.35 \pm 0.03 \mathrm{~A}$ & $48.03 \pm 1.15 \mathrm{~A}$ & $2.44 \pm 0.52 \mathrm{~A}$ & $80.13 \pm 4.24 \mathrm{~A}$ & $28.0 \pm 1.40 \mathrm{~A}$ & $33.0 \pm 1.73 \mathrm{~A}$ & $39.0 \pm 1.60 \mathrm{~A}$ \\
\hline LMR3 & $1.33 \pm 0.03 \mathrm{~A}$ & $48.83 \pm 1.10 \mathrm{~A}$ & $2.39 \pm 0.67 \mathrm{~A}$ & $80.2 \pm 3.27 \mathrm{~A}$ & $26.0 \pm 1.80 \mathrm{~A}$ & $33.33 \pm 2.52 \mathrm{~A}$ & $40.67 \pm 3.21 \mathrm{~A}$ \\
\hline SMR1 & $1.35 \pm 0.02 \mathrm{~A}$ & $48.2 \pm 0.95 \mathrm{~A}$ & $2.58 \pm 0.42 \mathrm{~A}$ & $79.53 \pm 1.80 \mathrm{~A}$ & $25.0 \pm 2.65 \mathrm{~A}$ & $30.67 \pm 5.51 \mathrm{~A}$ & $44.33 \pm 8.14 \mathrm{~A}$ \\
\hline SMR2 & $1.32 \pm 0.01 \mathrm{~A}$ & $49.2 \pm 0.35 \mathrm{~A}$ & $2.49 \pm 0.42 \mathrm{~A}$ & $81.07 \pm 3.79 \mathrm{~A}$ & $22.67 \pm 1.53 \mathrm{~A}$ & $28.67 \pm 1.53 \mathrm{~A}$ & $48.67 \pm 3.06 \mathrm{~A}$ \\
\hline SMR3 & $1.35 \pm 0.03 \mathrm{~A}$ & $48.2 \pm 1.15 \mathrm{~A}$ & $2.42 \pm 0.39 \mathrm{~A}$ & $82.07 \pm 1.98 \mathrm{~A}$ & $24.33 \pm 2.08 \mathrm{~A}$ & $29.0 \pm 1.60 \mathrm{~A}$ & $46.67 \pm 3.06 \mathrm{~A}$ \\
\hline CFL10 & $1.34 \pm 0.03 \mathrm{~A}$ & $48.67 \pm 1.19 \mathrm{~A}$ & $2.39 \pm 0.49 \mathrm{~A}$ & $80.37 \pm 2.36 \mathrm{~A}$ & $26.0 \pm 1.30 \mathrm{~A}$ & $33.0 \pm 1.40 \mathrm{~A}$ & $41.0 \pm 1.73 \mathrm{~A}$ \\
\hline CFL20 & $1.34 \pm 0.03 \mathrm{~A}$ & $48.5 \pm 1.11 \mathrm{~A}$ & $2.33 \pm 0.66 \mathrm{~A}$ & $80.73 \pm 4.1 \mathrm{~A}$ & $27.0 \pm 1.10 \mathrm{~A}$ & $31.33 \pm 3.51 \mathrm{~A}$ & $41.67 \pm 3.51 \mathrm{~A}$ \\
\hline CFL30 & $1.32 \pm 0.01 \mathrm{~A}$ & $49.27 \pm 0.45 \mathrm{~A}$ & $2.46 \pm 0.35 \mathrm{~A}$ & $81.13 \pm 2.24 \mathrm{~A}$ & $26.67 \pm 0.58 \mathrm{~A}$ & $29.0 \pm 2.30 \mathrm{~A}$ & $44.33 \pm 2.52 \mathrm{~A}$ \\
\hline
\end{tabular}

Table 2 Pearson correlations between runoff, sediment yield, targeted soil properties, canopy cover, and treatment

\begin{tabular}{|l|c|c|c|c|c|c|c|c|c|}
\hline \multicolumn{1}{|c|}{ Variable } & $\begin{array}{c}\text { Sediment } \\
\text { yield } \\
\mathrm{g} \mathrm{m}^{-2}\end{array}$ & $\begin{array}{c}\text { Runoff } \\
\mathrm{mm}\end{array}$ & $\begin{array}{c}\text { Bulk density } \\
\mathrm{Mg} \mathrm{m}^{-3}\end{array}$ & $\begin{array}{c}\text { Total } \\
\text { porosity } \\
\%\end{array}$ & $\begin{array}{c}\text { Organic } \\
\text { matter } \\
\text { content, } \%\end{array}$ & $\begin{array}{c}\text { Canopy } \\
\text { cover } \\
\%\end{array}$ & $\begin{array}{c}\text { Sand } \\
\%\end{array}$ & $\begin{array}{c}\text { Clay } \\
\%\end{array}$ & $\begin{array}{c}\text { Silt } \\
\%\end{array}$ \\
\hline Treatment & $-0.78^{* *}$ & $-0.75^{* *}$ & $-0.36^{\text {ns }}$ & $0.35^{\text {ns }}$ & $-0.13^{\text {ns }}$ & $0.10^{\text {ns }}$ & $0.15^{\text {ns }}$ & $-0.37^{\text {ns }}$ & $0.18^{\text {ns }}$ \\
\hline Sediment yield, g m ${ }^{-2}$ & 1 & $-0.77^{* *}$ & $0.32^{\text {ns }}$ & $-0.31^{\text {ns }}$ & $0.26^{\text {ns }}$ & $0.08^{\text {ns }}$ & $-0.36^{\text {ns }}$ & $0.13^{\text {ns }}$ & $0.07^{\text {ns }}$ \\
\hline Runoff, mm & - & 1 & $0.27^{\text {ns }}$ & $-0.27^{\text {ns }}$ & $0.16^{\text {ns }}$ & $-0.09^{\text {ns }}$ & $-0.41^{\text {ns }}$ & $0.07^{\text {ns }}$ & $0.14^{\text {ns }}$ \\
\hline Bulk density, Mg m ${ }^{-3}$ & - & - & 1 & $-1.00^{* *}$ & $0.15^{\text {ns }}$ & $0.18^{\text {ns }}$ & $0.03^{\text {ns }}$ & $0.10^{\text {ns }}$ & $-0.08^{\text {ns }}$ \\
\hline Total porosity, $\%$ & - & - & - & 1 & $-0.15^{\text {ns }}$ & $-0.19^{\text {ns }}$ & $-0.02^{\text {ns }}$ & $-0.09^{\text {ns }}$ & $0.07^{\text {ns }}$ \\
\hline Organic matter content, \% & - & - & - & - & 1 & $0.12^{\text {ns }}$ & $-0.29^{\text {ns }}$ & $0.17^{\text {ns }}$ & $0.25^{\text {ns }}$ \\
\hline Canopy cover, $\%$ & - & - & - & - & - & 1 & $-0.16^{\text {ns }}$ & $-0.12^{\text {ns }}$ & $0.15^{\text {ns }}$ \\
\hline Sand, \% & - & - & - & - & - & - & 1 & $0.54^{* *}$ & $-0.82^{* *}$ \\
\hline Clay, $\%$ & - & - & - & - & - & - & - & 1 & $-0.92^{* *}$ \\
\hline Silt, $\%$ & - & - & - & - & - & - & - & - & 1 \\
\hline
\end{tabular}

Note: ${ }^{* *} p<0.01 ;{ }^{\text {ns. }}$ not significant 
Table 3 ANOVA test results referred to the treatment effect on runoff and sediment yield

\begin{tabular}{|c|c|c|c|c|c|}
\hline \multirow{2}{*}{ Source } & \multirow{2}{*}{ d.f. } & \multicolumn{2}{|c|}{$F$} & $P$ value & \\
\cline { 3 - 6 } & & $\begin{array}{c}\text { Runoff } \\
\mathrm{mm}\end{array}$ & $\begin{array}{c}\text { Sediment } \\
\text { yield, } \mathrm{g} \mathrm{m}^{2}\end{array}$ & Runoff & $\begin{array}{c}\text { Sediment } \\
\text { yield }\end{array}$ \\
\hline Treatment & 9 & 29.01 & 41.06 & $\leq 0.001^{* *}$ & $\leq 0.001^{* *}$ \\
\hline
\end{tabular}

Note: ${ }^{* *} p<0.01$

Table 4 Mean ( \pm SD) of runoff, sediment yield, and runoff coefficient on different treatments; $U=$ Untreated area, LMR1 = Litter mulch rate of $0.62 \mathrm{~kg} \mathrm{~m}^{-2}, \mathrm{LMR} 2=$ Litter mulch rate of $1.24 \mathrm{~kg} \mathrm{~m}^{-2}$, LMR3 = Litter mulch rate of $1.86 \mathrm{~kg} \mathrm{~m}^{-2}, \mathrm{SMR} 1=$ Straw mulch rate of $0.45 \mathrm{~kg} \mathrm{~m}^{-2}, \mathrm{SMR} 2=$ Straw mulch rate of $0.92 \mathrm{~kg} \mathrm{~m}^{-2}$, SMR3 $=$ Straw mulch rate of $1.34 \mathrm{~kg} \mathrm{~m}^{-2}$, CFL10 = contour-felled logs with distance of $10 \mathrm{~m}, \mathrm{CFL} 20=$ contour-felled logs with distance of $20 \mathrm{~m}, \mathrm{CFL} 30$ = contour-felled logs with distance of $30 \mathrm{~m}$

\begin{tabular}{|c|c|c|c|}
\hline Treatment & $\begin{array}{c}\text { Runoff } \\
\mathrm{mm}\end{array}$ & $\begin{array}{c}\text { Sediment yield } \\
\mathrm{g} \mathrm{m}^{2}\end{array}$ & Runoff coefficient \\
\hline $\mathrm{U}$ & $2.36 \pm 0.61 \mathrm{~A}$ & $11.84 \pm 2.37 \mathrm{~A}$ & $0.059 \pm 0.009 \mathrm{~A}$ \\
\hline LMR1 & $1.38 \pm 0.47 \mathrm{BC}$ & $6.32 \pm 1.63 \mathrm{~B}$ & $0.030 \pm 0.002 \mathrm{~B}$ \\
\hline LMR2 & $1.07 \pm 0.42 \mathrm{CD}$ & $4.26 \pm 0.89 \mathrm{C}$ & $0.023 \pm 0.002 \mathrm{CD}$ \\
\hline LMR3 & $0.93 \pm 0.34 \mathrm{D}$ & $3.34 \pm 0.61 \mathrm{C}$ & $0.019 \pm 0.002 \mathrm{DE}$ \\
\hline SMR1 & $1.46 \pm 0.38 \mathrm{~B}$ & $6.76 \pm 1.76 \mathrm{~B}$ & $0.032 \pm 0.003 \mathrm{~B}$ \\
\hline SMR2 & $1.17 \pm 0.29 \mathrm{BC}$ & $4.48 \pm 0.82 \mathrm{C}$ & $0.025 \pm 0.004 \mathrm{C}$ \\
\hline SMR3 & $1.06 \pm 0.23 \mathrm{CD}$ & $3.56 \pm 0.68 \mathrm{C}$ & $0.022 \pm 0.003 \mathrm{CD}$ \\
\hline CFL10 & $0.39 \pm 0.13 \mathrm{~F}$ & $1.11 \pm 0.17 \mathrm{D}$ & $0.007 \pm 0.001 \mathrm{~F}$ \\
\hline CFL20 & $0.28 \pm 0.11 \mathrm{G}$ & $0.63 \pm 0.12 \mathrm{D}$ & $0.005 \pm 0.001 \mathrm{~F}$ \\
\hline CFL30 & $0.69 \pm 0.17 \mathrm{E}$ & $1.38 \pm 0.21 \mathrm{D}$ & $0.014 \pm 0.002 \mathrm{E}$ \\
\hline
\end{tabular}

Note: Different letters after means within the same column indicate significant differences by Duncan test $(p<0.05)$

\section{Discussion}

Several studies have demonstrated a clear relationship between soil compaction and runoff following machinery-traffic, as soil compaction leads to increase soil bulk density, decrease total porosity and aeration, increase soil strength, which results in a reduction of water infiltration, and increase of surface runoff flow (Ekwue and Harrilal 2010, Majnounian and Jourgholami 2013, Etehadi Abari et al. 2017, Jourgholami et al. 2018a and $b$ ). The following sub-chapters have discussed the studied treatments, mulch rate, distance between logs, and rainfall intensity.
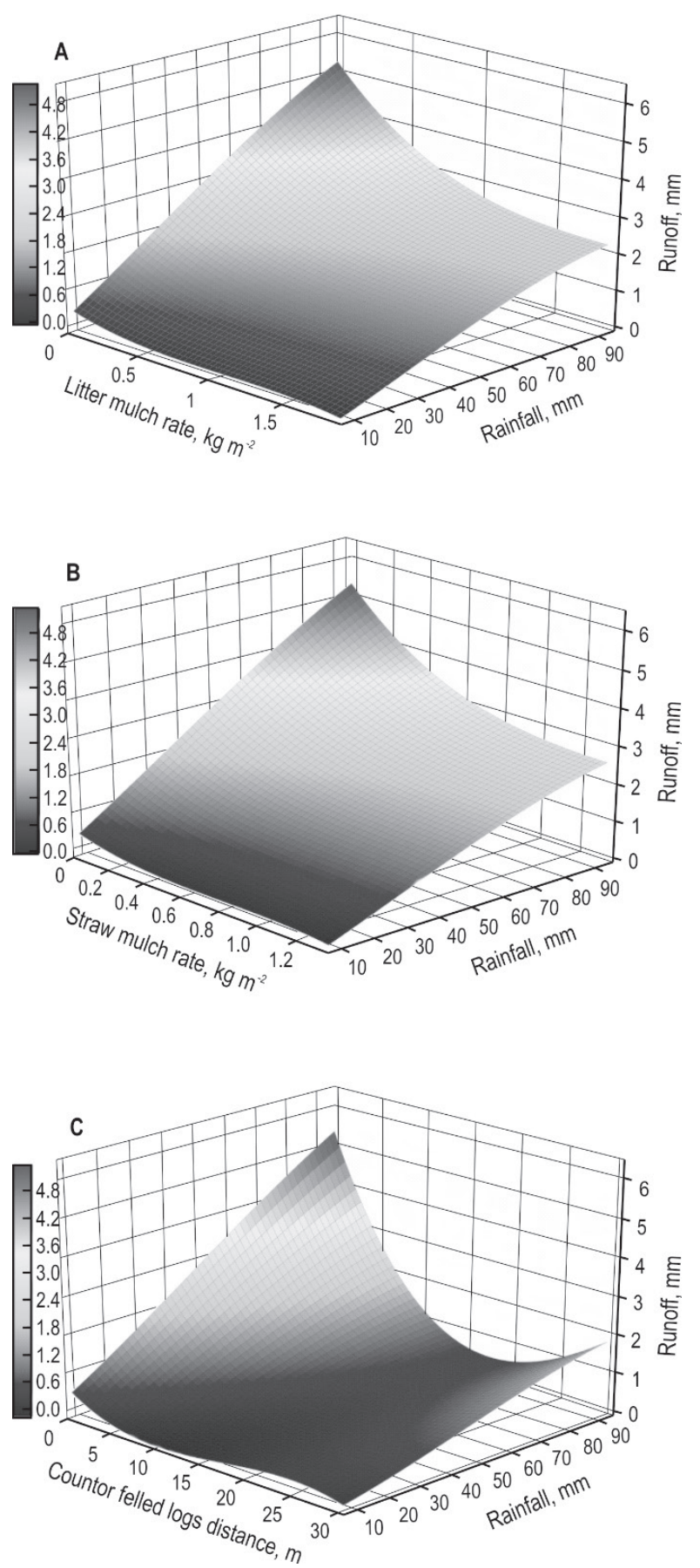

Fig. 2 Predicted runoff $(\mathrm{y}, \mathrm{mm})$ as a function of rainfall intensity $(\mathrm{Rl}, \mathrm{mm})$ and litter mulch rate (LMR, A), straw mulch rate (SMR, B), and contour-felled logs with different distance (CFL, C) based on multivariate polynomial regression analysis

\subsection{Litter and Straw}

In line with previous studies (Li et al. 2014, Jourgholami et al. 2019a), our data indicated that the runoff and sediment yield in the litter and mulch 

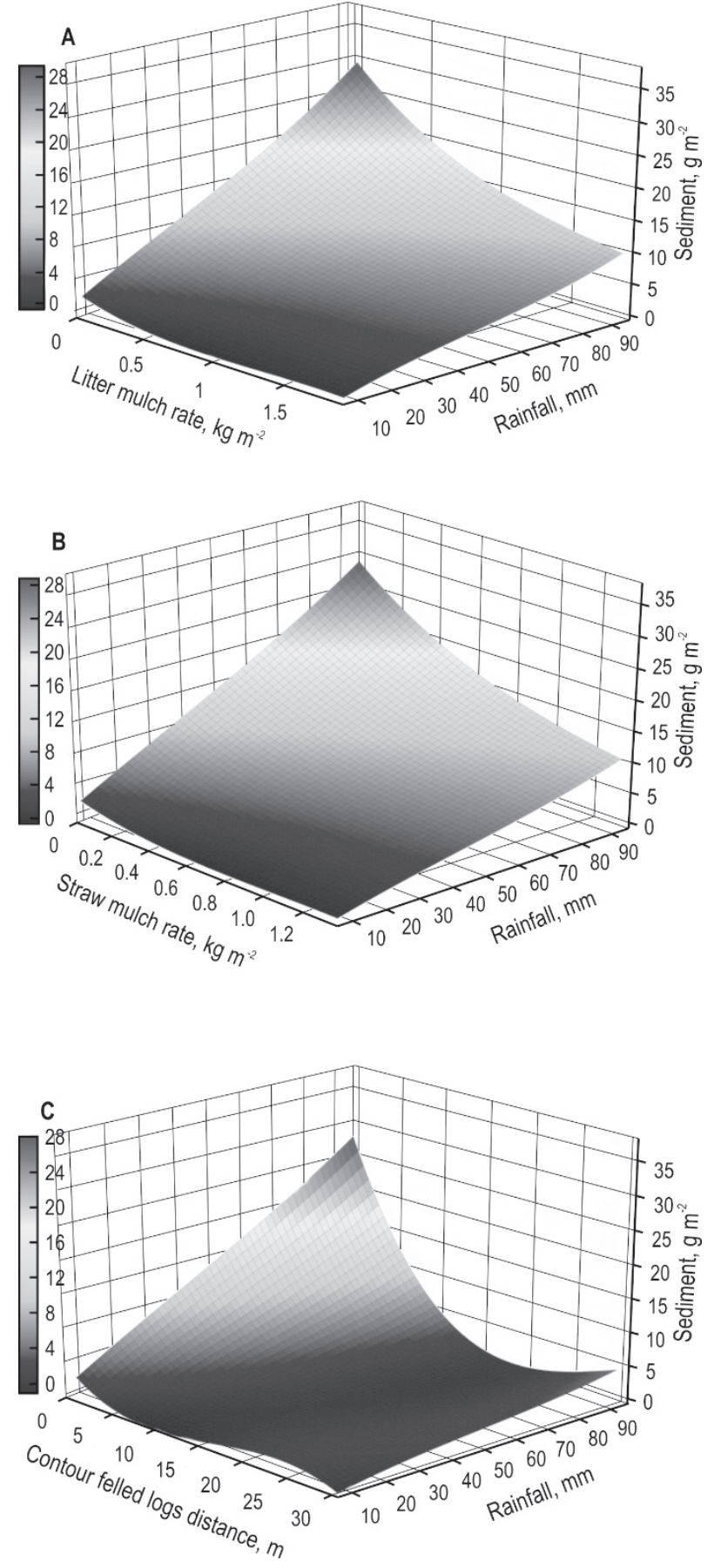

Fig. 3 Predicted sediment $\left(y, \mathrm{~g} \mathrm{~m}^{-2}\right)$ as a function of rainfall intensity $(\mathrm{Rl}, \mathrm{mm})$ and litter mulch rate $(\mathrm{LMR}, \mathrm{A})$, straw mulch rate (SMR, B), and contour-felled logs with different distance (CFL, C) based on multivariate polynomial regression analysis

treatments were lower compared to the $\mathrm{U}$ treatment. The key role of mulch spreading on surface mineral soil is to increase the ground cover, which leads to protect soil surface from crusting, enhance soil aggre- gates stability, increase infiltration, resulting in a decrease in rills development (Jordán et al. 2010, Robichaud et al. 2013). The mulch application rate is an important issue that should be taken into account. Results of the current study show that runoff, runoff coefficient, and sediment yield decreased as the applying rates of litter and straw mulch increased in the range of 0.62 to $1.86 \mathrm{~kg} \mathrm{~m}^{-2}$ and 0.45 to $1.34 \mathrm{~kg} \mathrm{~m}^{-2}$, respectively. These results are consistent with the findings by Wagenbrenner et al. (2010) and Robichaud et al. (2013), who stated that the depth and thickness of mulch cover can influence the generation of runoff and sediment yield. Furthermore, when the applying rates of litter and straw mulch were increased, the surface flow continuity could not be formed and overland flow decreased (Xing et al. 2016, Zhang et al. 2018). In line with previous studies (Li et al. 2014, Jourgholami et al. 2018b, Jourgholami et al. 2019a), our study indicated that both litter and straw absorb the raindrop and throughfall energy, increase the surface roughness, which leads to increased infiltration rate, delayed concentration time, and reduced runoff and sediment yield. Oppositely, the higher runoff was observed in straw mulch cover than in the bare soil according to previous work (McGregor et al. 1988, Jourgholami and Etehadi Abari 2017), which can be explained by the impervious nature of surface cover with straw mulch, which in turn leads to the concentration of the surface flow, which resulted in a decrease in infiltration rate and increase in surface flow. Additionally, litter and straw mulches can develop mini-dams, which resulted in a slower surface water flow and greater infiltration rate and sediment deposition (Foltz and Dooley 2003). In line with previous studies (Li et al. 2014, Fernández and Vega 2016, Jourgholami and Etehadi Abari 2017), our study indicated that runoff and sediment were less in LMR1 and SMR1 than litter and straw mulch with greater applying rate. Fernández and Vega (2016) and Jourgholami and Etehadi Abari (2017) pointed out that the mulch materials were eliminated from the bare surface soil over a period of a few months after applying. When the low application rate of litter and straw mulch was combined with the high rainfall intensity, the soil detachment could be increased, which in turn resulted in an increase in substantial sediment yield over a one-year period after soil compaction and removal of the litter layer.

Our data indicate that the greatest amounts of runoff were found in the first testing rates of both litter and straw mulching, and further increasing the litter and straw mass had no substantial effects on decreasing runoff. Similar to our data, Jourgholami et al. (2019a) reported that by increasing the litter rate from 0.42 to 
$1.31 \mathrm{~kg} \mathrm{~m}^{-2}$, runoff decreased by $75 \%$; and by further increasing the litter rate from 1.31, and $1.69 \mathrm{~kg} \mathrm{~m}^{-2}$, only a $4 \%$ decrease in runoff was observed. Similarly, Li et al. (2014) reported that subsequent increasing of the litter mass $>0.3 \mathrm{~kg} \mathrm{~m}^{-2}$ had no significant change in runoff. According to previous work ( $\mathrm{Li}$ et al. 2014), consistency in runoff response after additional increase in litter and straw mulch can be attributed to the formation of flow channel in the upper layer, which in turn resulted in an increase in the overland flow on the surface layer.

The longevity and durability of litter and straw mulch is an important factor that affected the efficacy of rehabilitation treatments on machine operating trails. Within one or two years after applying mulch, the decomposition of mulch reduces its effectiveness to suppress runoff and sediment yield. Some mulch, such as wood shreds, is not effective in mitigating sediment on decommissioned forest roads because of wash away after the first rainfall events (Foltz 2012), which should be considered when applying litter and straw mulch on the compacted bare soil. Similar to our data, Xing et al. (2016) reported that increasing mulch cover increases the runoff and sediment due to enhanced water infiltration and reinfiltration processes. We observed that the straw mulch was sensitive to wind, which led to the removal of the straw mulch from the surface soil and also to inconsistent mulch coverage of machine operating trails, which was confirmed by previous observations (Robichaud et al. 2013, Jourgholami and Etehadi Abari 2017). Additionally, rice straw can introduce invasive species to forest ecosystems (Robichaud et al. 2013).

\subsection{Contour-Felled Logs}

Previous studies have concluded that log erosion barriers, such as contour-felled logs, could be an effective solution to slow the velocity of surface runoff and trap the detached soil particles, if contour-felled logs were installed correctly and had an adequate sediment storage capacity (Wagenbrenner et al. 2006, Yanosek et al. 2006, Kim et al. 2008, Robichaud et al. 2008a, Naghdi et al. 2017). Contour-felled logs provided the storage capacity for runoff and sediment especially in high rainfall intensity, which resulted in a greater concentration time and infiltration rate than the litter and straw mulch, which led to a significant reduction of the runoff and sediment yield (Robichaud et al. 2008b).

Results of the current study show that runoff in the contour-felled logs decreased by increasing the distance between them from 10 to $20 \mathrm{~m}$ (in range of $83.5-88.1 \%$ ), and increased by increasing the distance from 20 to $30 \mathrm{~m}$ (70.8\%), compared to U treatment. One of the impor- tant factors affecting the efficacy of contour-felled logs to suppress runoff and sediment yield is the distance between them (Robichaud et al. 2008a, Fernández and Vega 2016). Our study is in line with the results of Prats et al. (2016), which confirmed that runoff in the slope length of $0.5 \mathrm{~m}$ was ten times higher than in a $25 \mathrm{~m}$ length in the first year after a wildfire. In the current study, the concentration time (a concept used in hydrology to measure the response of a watershed to a rain event and defined as the time needed for water to flow from the most remote point in a watershed to the watershed outlet) and the time needed to start surface flow increased, since the distance between the contour-felled logs increased from 10 to $20 \mathrm{~m}$. However, further increasing the distance between contourfelled logs resulted in a filling of the storage capacity, overflow occurred, and then runoff increased especially in the high intensity rainfall. Previous studies found that runoff decreased significantly by increasing the distance between logs (Boix-Fayos et al. 2007, Prats et al. 2016, Xing et al. 2016, Zhang et al. 2018). Similarly, Zhang et al. (2018) indicated that surface runoff flow occurred, as the rainfall duration surpasses the concentration time. According to previous work (Zhang et al. 2018), flow continuity developed below the mulch layer following the high rainfall intensity because of the absence of the humus layer, which in turn led to increase flow velocity, soil particle detachment and sediment yield. In contrast, Wagenbrenner et al. (2006) found that the effectiveness of rehabilitation treatments to suppress runoff and sediment was greater with mulching than with contour-felled logs three years after a fire due to enhanced ground coverage.

\subsection{Rainfall Intensity}

Results of the current study demonstrated that runoff, runoff coefficient, and sediment yield increased by increasing the rainfall intensity in all the treatments (i.e., litter, straw, and contour-felled logs). Similar to our data, several studies pointed out that strong relationships were observed between rainfall intensity and runoff, runoff coefficient, and sediment yield (Geißler et al. 2012, Fernández and Vega 2016, SosaPérez and MacDonald 2017, Jourgholami et al. 2019a). According to previous work (Sosa-Pérez and MacDonald 2017), rainfall intensity regulates the rainsplash soil loss. In line with previous studies ( $\mathrm{Li}$ et al. 2014, Jourgholami et al. 2019a), our study indicated that the effect of rainfall intensity to change runoff and sediment yield after litter and straw mulching was greater in low applying rates than in high rates of mulch. Also, previous studies reported 
that the combinations of rainfall intensity and mulch rates (or distances between contour-felled logs) governs the infiltration rate and surface water flow, which influences the velocity energy of surface flow, detachment of soil particles, and transportation of sediment (Li et al. 2014, Sosa-Pérez and MacDonald 2017, Jourgholami et al. 2019a). Similar to our data, previous studies reported that the high rainfall intensity resulted in the greater runoff coefficient, which in turn led to increase runoff flow and increase detachment soil particles, and increase sediment deposition into lowland infrastructures (Parsons et al. 2006, Xing et al. 2016). Furthermore, the peak discharge of runoff increased at the corresponding infiltration rate by increasing the rainfall intensity (Kinnell 2016).

Our data supported the hypothesis that the application of organic mulch amendments, such as straw and leaf litter, and contour-felled logs, may suppress runoff, sediment yield, and the runoff coefficient.

\section{Conclusions}

Our study demonstrated that the effects of three post-harvest rehabilitation treatments (i.e. straw and leaf litter mulch, and contour-felled logs) can be effective to mitigate surface runoff and sediment yield under the natural conditions on the machine operating trails. Our findings revealed that contour-felled logs with different distance were found to be more effective than the litter and straw mulch to reduce runoff, runoff coefficient, and sediment yield compared to untreated treatment. The application rate of $1.24 \mathrm{~kg} \mathrm{~m}^{-2}$ was observed to be an optimal mass for litter mulch, while further increase of litter depth had no significant effect in decreasing runoff and sediment yield; the optimal applying rate for straw mulch was observed to be $0.92 \mathrm{~kg} \mathrm{~m}^{-2}$ in our study. Our findings suggest that contour-felled logs with a distance of $20 \mathrm{~m}$ proved to be more effective than others to mitigate runoff and sediment yield. Our study highlighted that the combination of rainfall intensity and mulch rates (or distances between contour-felled logs) controls the infiltration rate and surface water flow, which in turn resulted in a decrease in runoff and sediment yield. Regardless of the mulching rates for litter and straw, and distances between contour-felled logs, runoff and sediment steadily increased as rainfall intensity increased. As a management measure, the results of the current study proposed that the contour-felled logs with a distance of $20 \mathrm{~m}$ be prescribed to protect the machine operating trails in the Hyrcanian forest from the negative effects of surface waterflow.

\section{References}

Batey, T., 2009: Soil compaction and soil management-a review. Soil Use manage. 25(2): 335-345. https://doi. org/10.1111/j.1475-2743.2009.00236.x

Boix-Fayos, C., Martinez-Mena, M., Calvo-Cases, A., ArnauRosalen, E., Albaladejo, J., Castillo, V., 2007: Causes and underlying processes of measurement variability in field erosion plots in Mediterranean conditions. Earth Surf. Process. Landf. 32(1): 85-101. https://doi.org/10.1002/esp.1382

Cristan, R., Aust, W.M., Bolding, M.C., Barrett, S.M., Munsell, J.F., Schilling, E., 2016: Effectiveness of forestry best management practices in the United States: Literature review. For. Ecol. Manage. 360(1): 133-151. https://doi. org/10.1016/j.foreco.2015.10.025

Ekwue, E.I., Harrilal, A., 2010: Effect of soil type, peat, slope, compaction effort and their interactions on infiltration, runoff and raindrop erosion of some Trinidadian soils. Biosyst. Eng. 105(1): 112-118. https://doi.org/10.1016/j.biosystemseng.2009.10.001

Etehadi Abari, M., Majnounian, B., Malekian, A., Jourgholami, M., 2017: Effects of forest harvesting on runoff and sediment characteristics in the Hyrcanian forests, northern Iran. Eur. J. Forest Res. 136(2): 375-386. https://doi. org/10.1007/s10342-017-1038-3

Fernández, C., Vega, J.A., 2016: Are erosion barriers and straw mulching effective for controlling soil erosion after a high severity wildfire in NW Spain. Ecol. Eng. 87: 132-138. https://doi.org/10.1016/j.ecoleng.2015.11.047

Foltz, R.B., 2012: A comparison of three erosion control mulches on decommissioned forest road corridors in the northern Rocky Mountains, United States. J. Soil Water Conserv. 67(6): 536-544. https://doi:10.2489/jswc.67.6.536

Foltz, R.B., Dooley, J.H., 2003: Comparison of erosion reduction between wood strands and agricultural straw. T. ASAE 46: 1389-1396.

Gee, G.W., Bauder, J.W., 1986: Particle-size analysis. In: Klute, A., (Ed.), Methods of Soil Analysis, Part 1. Physical and Mineralogical Methods. Soil Science Society of America, Madison, WI: 383-411.

Geißler, C., Kühn, P., Böhnke, M., Bruelheide, H., Shi, X., Scholten, T., 2012: Splash erosion potential under tree canopies in subtropical SE China. Catena 91: 85-93. https://doi. org/10.1016/j.catena.2010.10.009

Hansson, L., Ring, E., Franko, M., Gärdenäs, A., 2018: Soil temperature and water content dynamics after disc trenching a sub- xeric Scots pine clearcut in central Sweden. Geoderma 327: 85-96. https://doi.org/10.1016/j.geoderma.2018.04.023

Hamza, M., Anderson, W., 2005: Soil compaction in cropping systems: A review of the nature, causes and possible solutions. Soil Tillage Res. 82(2): 121-145. https://doi. org/10.1016/j.still.2004.08.009 
Jiang, M-H., Lin, T-C., Shaner, P-J.L., Lyu, M-K., Xu, C., Xie, J-S., Lin, C-F., Yang, Z-J., Yang, Y-S., 2019: Understory interception contributed to the convergence of surface runoff between a Chinese fir plantation and a secondary broadleaf forest. J. Hydrol. 574: 862-871. https://doi.org/10.1016/j.jhydrol.2019.04.088

Jordán, A., Zavala, L.M., Gil, J., 2010: Effects of mulching on soil physical properties and runoff under semi-arid conditions in southern Spain. Catena 81(1): 77-85. https://doi. org/10.1016/j.catena.2010.01.007

Jourgholami, M., Etehadi Abari, M., 2017: Effectiveness of sawdust and straw mulching on postharvest runoff and soil erosion of a skid trail in a mixed forest. Eco. Eng. 109(Part A): 1-9. https://doi.org/10.1016/j.ecoleng.2017.09.009

Jourgholami, M., Fathi, K., Labelle, E.R., 2018a: Effects of foliage and traffic intensity on runoff and sediment in skid trails after trafficking in a deciduous forest. Eur. J. Forest Res. 137(2): 223-235. https://doi.org/10.1007/s10342-018-1102-7

Jourgholami, M., Ghassemi, T., Labelle, E.R., 2019b: Soil physio-chemical and biological indicators to evaluate the restoration of compacted soil following reforestation. Ecol. Indic. 101: 102-110. https://doi.org/10.1016/j. ecolind.2019.01.009

Jourgholami, M., Khajavi, S., Labelle, E.R., 2018b: Mulching and water diversion structures on skid trails: Response of soil physical properties six years after harvesting. Ecol. Eng. 123: 1-9. https://doi.org/10.1016/j.ecoleng.2018.08.023

Jourgholami, M., Labelle, E.R., Feghhi, J., 2019a: Efficacy of leaf litter mulch to mitigate runoff and sediment yield following mechanized operations in the Hyrcanian mixed forests. J. Soils Sediments. 19(4): 2076-2088. https://doi. org/10.1007/s11368-018-2194-x

Kim, C-G., Shin, K., Joo, K.Y., Lee, K.S., Shin, S.K., Choung, Y., 2008: Effects of soil conservation measures in a partially vegetated area after forest fires. Sci. Total Environ. 399(1-3): 158-164. https://doi.org/10.1016/j.scitotenv.2008.03.034

Kim, J.K., Onda, Y., Kim, M.S., Yang, D.Y., 2014: Plot-scale study of surface runoff on well-covered forest floors under different canopy species. Quat. Int. 344: 75-85. https://doi. org/10.1016/j.quaint.2014.07.036

Kinnell, P.I.A., 2016: A review of the design and operation of runoff and soil loss plots. Catena 145: 257-265. https://doi. org/10.1016/j.catena.2016.06.013

Li, X., Niu, J., Xie, B., 2014: The effect of leaf litter cover on surface runoff and soil erosion in northern China. PLoS One 9(9): e107789. https://doi.org/10.1371/journal.pone.0107789

Majnounian, B., Jourgholami, M., 2013: Effect of rubber-tired cable skidder on soil compaction in Hyrcanian forest. Croat. J. For. Eng. 34(1): 123-135.

McGregor, K.C., Bengtson, R.L., Muchler, C.K., 1988: Effects of surface straw on interrill runoff and erosion of Grenada Silt Loam soil. T. ASAE 31(1): 111-116. https://doi. org/10.13031/2013.30675
Naghdi, R., Dalir, P., Gholami, V., Pourghasemi, H.R., 2017: Modeling of sediment generation from forest roads employing SEDMODL and its calibration for Hyrcanian forests in northern Iran. Environ. Earth. Sci. 76: Article number 414. https://doi.org/10.1007/s12665-017-6758-7

Nawaz, M.F., Bourrie, G., Trolard, F., Ranger, J., Gul, S., Niazi, N.K., 2016: Early detection of the effects of compaction in forested soils: evidence from selective extraction techniques. J. Soils sediments 16(9): 2223-2233. https://doi. org/10.1007/s11368-016-1434-1

Nawaz, M.F., Bourrie, G., Trolard, F., 2013: Soil compaction impact and modelling, A review. Agron. Sustain. Dev. 33(2): 291-309. https://doi.org/10.1007/s13593-011-0071-8

Parsons, A.J., Brazier, R.E., Wainwright, J., Powell, D.M., 2006: Scale relationships in hillslope runoff and erosion. Earth Surf. Process. Landf. 31(11): 1381-1393. https://doi. org/10.1002/esp.1345

Picchio, R., Neri, F., Petrini, E., Verani, S., Marchi, E., Certini, G., 2012: Machinery-induced soil compaction in thinning two pine stands in central Italy. For. Ecol. Man. 285: 38-43. https://doi.org/10.1016/j.foreco.2012.08.008

Picchio, R., Spina, R., Calienno, L., Venanzi, R., Lo Monaco, A., 2016: Forest operations to implement silvicultural treatments for multiple purposes. In: De Cinti et al. (Eds). From the experience of LIFE+ ManFor C.BD to the Manual of Best Practices in Sustainable Forest Management. Ital. J. Agron. 11(s1): 1-175.

Picchio, R., Tavankar, F., Bonyad, A., Mederski, P.S., Venanzi, R., Nikooy, M., 2019: Detailed Analysis of Residual Stand Damage Due to Winching on Steep Terrains. Small-scale For. 18(2): 255-277. https://doi.org/10.1007/s11842-019-09417-5

Poltorak, B.J., Labelle, E.R., Jaeger, D., 2018: Soil displacement during ground-based mechanized forest operations using mixed-wood brush mats. Soil Tillage Res. 179: 96-104. https://doi.org/10.1016/j.still.2018.02.005

Prats, S.A., Wagenbrenner, J., Malvar, M.C., Martins, M.A.S., Keizer, J.J., 2016: Mid-term and scaling effects of forest residue mulching on post-fire runoff and soil erosion. Sci. Total Environ. 573: 1242-1254. https://doi.org/10.1016/j.scitotenv.2016.04.064

Prats, S.A., Martins, M.A.S., Malvar, M.C., Ben-Hur, M., Keizer, J.J., 2014: Polyacrylamide application versus forest residue mulching for reducing post-fire runoff and soil erosion. Sci. Total Environ. 468-469: 464-474. https://doi. org/10.1016/j.scitotenv.2013.08.066

Robichaud, P.R., Lewis, S.A., Wagenbrenner, J.W., Ashmun, L.E., Robert, E., Brown, R.E., 2013: Post-fire mulching for runoff and erosion mitigation, Part I: Effectiveness at reducing hillslope erosion rates. Catena 105: 75-92. https://doi. org/10.1016/j.catena.2012.11.015

Robichaud, P.R., Pierson, F.B., Brown, R.E., Wagenbrenner, J.W., 2008a: Measuring effectiveness of three post-fire hillslope erosion barrier treatments, western Montana, USA. 
Hydrol. Process. 22(2): 159-170. https://doi.org/10.1002/ hyp. 6558

Robichaud, P.R., Wagenbrenner, J.W., Pierson, F.B., Spaeth, K.E., Ashmun, L.E., Moffet, C.A., 2016: Infiltration and interrill erosion rates after a wildfire in western Montana, USA. Catena 142: 77-88. https://doi.org/10.1016/j.catena.2016.01.027

Robichaud, P.R., Wagenbrenner, J.W., Brown, R.E., Wohlgemuth, P.M., Beyers, J.L., 2008b: Evaluating the effectiveness of contour-felled log erosion barriers as a post-fire runoff and erosion mitigation treatment in the western United States. Int. J. Wildland Fire. 17(2): 255-273. https://doi. org/10.1071/WF07032

Sinha, P., 2013: Multivariate Polynomial Regression in Data Mining: Methodology, Problems and Solutions. Int. J. Sci. Eng. Res. 4(12): 962-965.

Sayer, E.J., 2006: Using experimental manipulation to assess the roles of leaf litter in the functioning of forest ecosystems. Biol. Rev. 81(1): 1-31. https://doi.org/10.1017/ S1464793105006846

Smets, T., Poesen, J., Knapen, A., 2008: Spatial scale effects on the effectiveness of organic mulches in reducing soil erosion by water. Earth-Sci. Rev. 89(1-2): 1-12. https://doi. org/10.1016/j.earscirev.2008.04.001

Sosa-Pérez, G., MacDonald, L.H., 2017: Effects of closed roads, traffic, and road decommissioning on infiltration and sediment production: A comparative study using rainfall simulations. Catena 159: 93-105. https://doi.org/10.1016/j. catena.2017.08.004

Vega, J.A., Fernández, C., Fonturbel, T., 2015: Comparing the effectiveness of seeding and mulching + seeding in reducing soil erosion after a high severity fire in Galicia (NW Spain). Ecol. Eng. 74: 206-212. https://doi.org/10.1016/j.ecoleng.2014.10.019
Vega, J.A., Fernández, C., Fonturbel, T., González-Prieto, S., Jiménez, E., 2014: Testing the effects of straw mulching and herb seeding on soil erosion after fire in a gorse shrubland. Geoderma 223-225: 79-87. https://doi.org/10.1016/j.geoderma.2014.01.014

Wagenbrenner, J.W., MacDonald, L.H., Roug, D., 2006: Effectiveness of three post-fire rehabilitation treatments in the Colorado Front Range. Hydrol. Process. 20(14): 2989-3006. https://doi.org/10.1002/hyp.6146

Walkley, A., Black, I.A., 1934: An examination of the Degtjareff method for determining soil organic matter and a proposed modification of chromic acid titration method. Soil Sci. 37(1): 29-38. http://dx.doi.org/10.1097/00010694193401000-00003

Wagenbrenner, J.W., Robichaud, P.R., Elliot, W.J., 2010: Rill erosion in natural and disturbed forests: 2. Modeling Approaches. Water Resour. Res. 46 (10): W10507. https://doi. org/10.1029/2009WR008315

Wear, L.R., Aust, W.M., Bolding, M.C., Strahm, B.D., Dolloff, C.A., 2013: Effectiveness of best management practices for sediment reduction at operational forest stream crossings. For. Ecol. Manage. 289: 551-561. https://doi.org/10.1016/j. foreco.2012.10.035

Xing, W., Yang, P., Ren, S., Ao, C., Li, X., Gao, W., 2016: Slope length effects on processes of total nitrogen loss under simulated rainfall. Catena 139: 73-81. https://doi.org/10.1016/j. catena.2015.12.008

Yanosek, K.A., Foltz, R.B., Dooley, J.H., 2006: Performance assessment of wood strand erosion control materials among varying slopes, soil textures, and cover amounts. J. Soil Water Conserv. 61(2): 45-51.

Zhang, X., Hu, M., Guo, X., Yang, H., Zhang, Z., Zhang, K., 2018: Effects of topographic factors on runoff and soil loss in Southwest China. Catena 160: 394-402. https://doi. org/10.1016/j.catena.2017.10.013

(C) 2020 by the authors. Submitted for possible open access publication under the terms and conditions of the Creative Commons Attribution (CC BY) license (http://creativecommons.org/licenses/by/4.0/). 
M. Jourgholami et al. Effectiveness of Three Post-Harvest Rehabilitation Treatments for Runoff and Sediment ... (309-324)

\section{Appendix A}
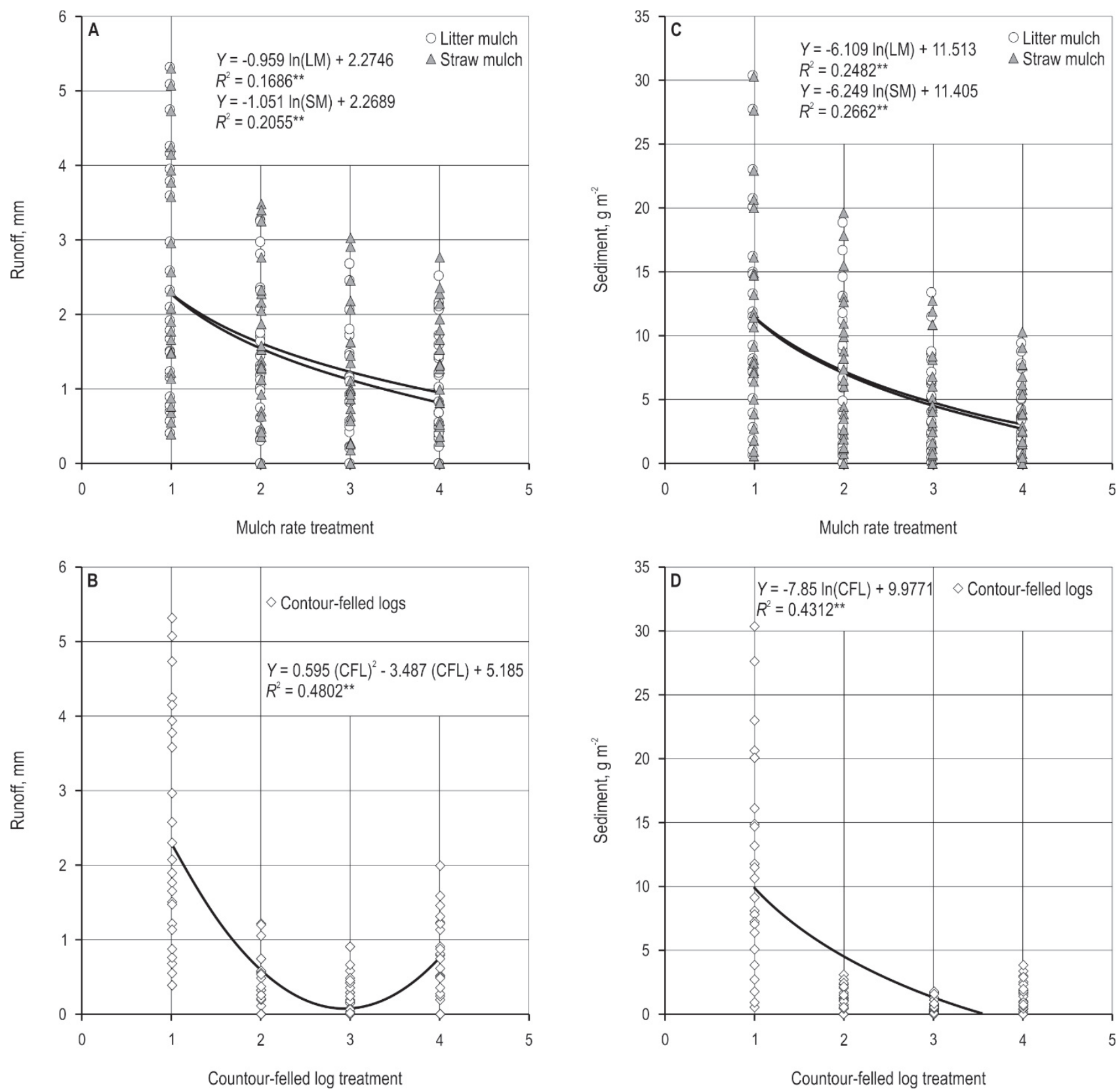

Fig. A1 Relationship between litter and straw mulch rate (A, C) and contour-felled logs with different distance (B, D) versus runoff and sediment yield. The unit of $x$ axes including 1, 2, 3 and 4 presents classes of variables as: 1: U; 2: LMR2, SMR2, CFL10; 3: LMR3, SMR3, CFL20; 4: LMR4, SMR4, CFL30. The regression equation and the coefficient of determination $\left(R^{2}\right)$ are shown in each graph. Note: $:: p<0.05$;

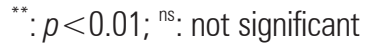



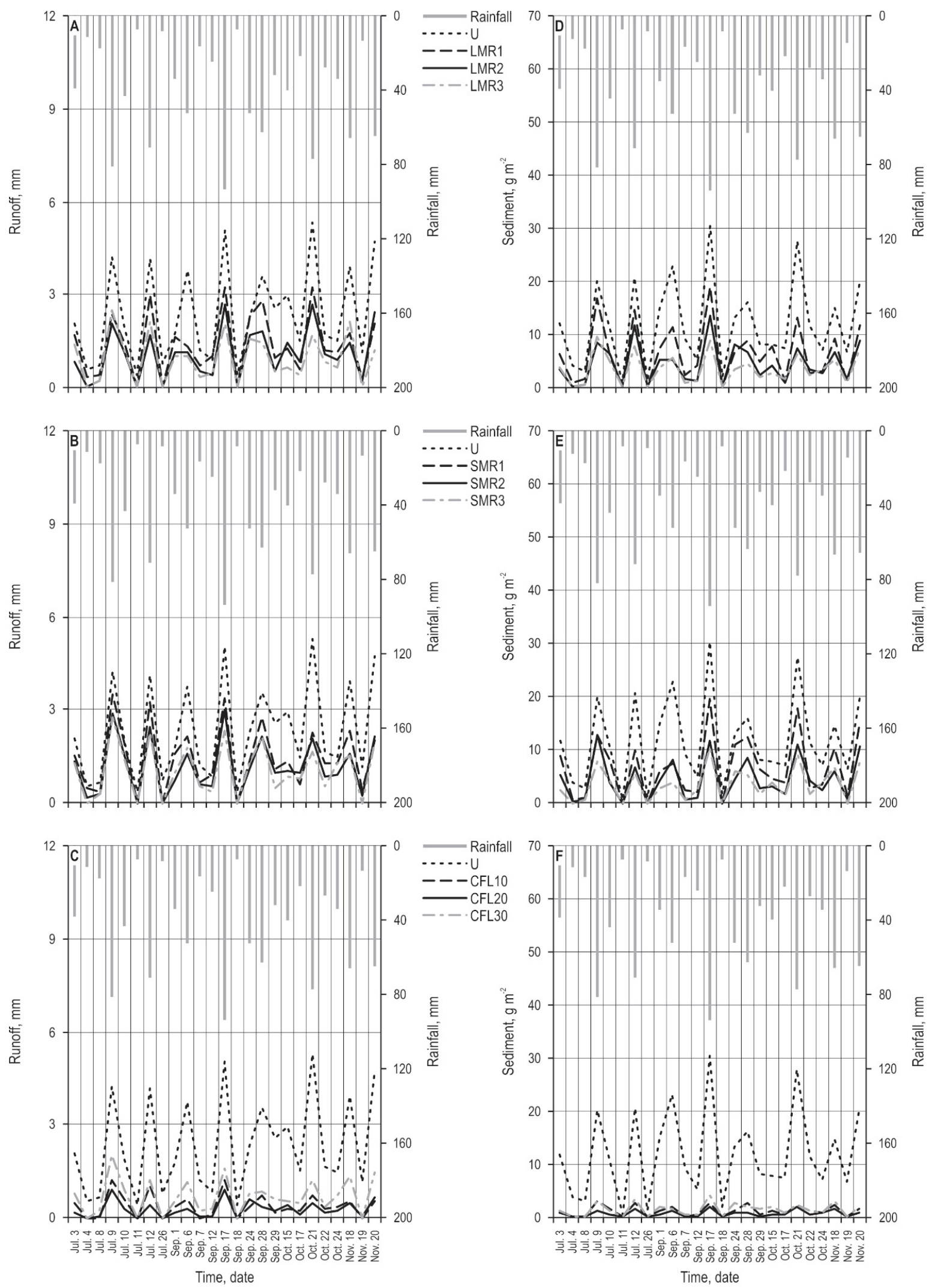

Fig. A2 Relationship between runoff $(\mathrm{mm})$ and sediment $\left(\mathrm{g} \mathrm{m}^{-2}\right)$ with daily rainfall $(\mathrm{mm})$ and different treatments including litter mulch rate $(A, D)$, straw mulch rate $(B, E)$, contour-felled logs with different distance $(C, F)$, compared to the untreated area $(U)$ 
Authors' addresses:

Prof. Meghdad Jourgholami, PhD * e-mail: mjgholami@ut.ac.ir Masoumeh Ahmadi, MSc e-mail: m.s.ahmadi@ut.ac.ir University of Tehran University College of Agriculture \& Natural Resources Faculty of Natural Resources Department of Forestry and Forest Economics 31585-4314, Zob-e-Ahan Street

Karaj

Alborz

IRAN

Prof. Farzam Tavankar, PhD e-mail: tavankar@aukh.ac.ir Islamic Azad University, Khalkhal Branch, Iran Faculty of Natural resources Department of Forestry Valie Asr Street 56817-31367, Khalkhal City Ardebil Province IRAN

Prof. Rodolfo Picchio, PhD e-mail: r.picchio@unitus.it University of Tuscia Department of agricultural and forest sciences (DAFNE)

Via San Camillo de Lellis, snc 01100, Viterbo

* Corresponding author 